\title{
Biodistribution Study of the Anaesthetic Sodium Phenobarbital Labelled with Technetium-99m in Swiss Mice Infected with Schistosoma mansoni Sambon, 1907
}

\author{
Susana Balmant Emerique Simões, José Roberto Machado-Silva/ ${ }^{+}$, Bianca \\ Gutfilen*, Octávio Augusto França Presgrave** Márcia Betânia Oliveira*, \\ Mario Bernardo-Filho*/***
}

\begin{abstract}
Departamento de Patologia e Laboratórios, Faculdade de Ciências Médicas, Universidade do Estado do Rio de Janeiro, Av. 28 de Setembro 87, 20551-030 Rio de Janeiro, RJ, Brasil *Departamento de Biofísica e Biometria, Instituto de Biologia, Universidade do Estado do Rio Janeiro, 20551-030 Rio de Janeiro, RJ, Brasil

**Departamento de Farmacologia e Toxicologia, Instituto Nacional de Controle de Qualidade em Saúde, Fundação Oswaldo Cruz, Av. Brasil 4365, 21045-900 Rio de Janeiro, RJ, Brasil *** Instituto Nacional do Câncer, Centro de Pesquisa Básica, Praça da Cruz Vermelha 23, 20230-130 Rio de Janeiro, RJ, Brasil
\end{abstract}

Technetium-99m $\left({ }^{99 m} T c\right)$ is a radionuclide that has negligible enviromnental impact, is easily available, inexpensive and can be used as a radioactive tracer in biological experiences. In order to know the mode of action of sodium phenobarbital in moving adult Schistosoma mansoni worms from mesenteric veins to the liver, we labelled sodium phenobarbital (PBBT) with ${ }^{99 m} \mathrm{Tc}$ and a biodistribution study in infected and non-infected Swiss mice was performed. The PBBT was incubated with stannous chloride used as reducing agent and with ${ }^{99 m} \mathrm{Tc}$, as sodium pertechnetate. The radioactivity labelling (\%) was determined by paper ascending chromatography perfomed with acetone (solvent). The ${ }^{99 m}$ Tc-PBBT was administered by intraperitoneal route to Swiss mice infected eight weeks before. The animals were perfused after diferent periods of time $(0,1,2,3,4 \mathrm{hr})$ when blood, spleen, liver, portal vein, mesenteric veins, stomach, kidneys and adult worms were isolated. The radioactivity present in these samples was counted in a well counter and the percentage was determined. The radioactivity was mainly taken up by the blood, kidney, liver and spleen. No radioactivity was found on the adult worms. We concluded that the worm shift was due to an action on the host of the sodium phenobarbital.

Key words: Schistosoma mansoni - technetium-99m-sodium phenobarbital - biodistribution - Swiss mice

An unexpected migration of the adult worm of Schistosoma mansoni is observed in albino mice treated with schistosomicides. The worm migrates from mesenteric veins to the liver (Woolhouse \& Kaye 1977). This same fact can be oberved when these mice are submitted to anesthaestic drugs, as ether and chlorophorm (Khayyal 1965), nembutal (Goldsmith \& Kean 1966), fluotane (Motta et al. 1968), halotane (Cunha-Melo \& Coelho 1986), pentobarbital and sodium phenobarbital (Machado e Silva et al. 1993, 1996). However, it is not established if this migration is due to the action of the drug in the host and/or directly in the adult worms. The absence of an efficient methodology to perform this study is the reason for this doubt.

The employement of radionuclides in different biological evaluations has permitted a strong tech-

${ }^{+}$Corresponding author. Fax:+55-21-204.2343

Received 16 April 1997

Accepted 30 June 1997 nical-scientific development in various areas of the knowledge. With radioisotopic methodologies, in laboratory conditions, several characteristics of the interaction of the S. mansoni with the experimental host have been studied (Christensen 1977, Pinto et al. 1990). Despite the importance of the acquired information using these techniques, they are sometimes restricted, mainly due to (i) the non availability of the radionuclide, (ii) the high costs of the method and (iii) the radioprotection problems (Bernardo-Filho et al. 1992).

Technetium- $99 \mathrm{~m}\left({ }^{99 \mathrm{~m}} \mathrm{Tc}\right)$ is a radionuclide that presents several relevant biological, chemical, physical and economical charactheristics (Hladik III et al. 1987, Saha 1992, Early \& Soddee 1995). It has been widely utilized to label radiopharmaceuticals to be used in nuclear medicine procedures (Bernardo-Filho et al. 1994), as well as radiotracers to be employed in basic research (BernardoFilho et al. 1992, Ripoll-Hamer et al. 1995, Santos et al. 1995). In parasitological evaluations, it has been used successfully, as an alternative radionuclide to get information about the $S$. mansoni life 
cycle. ${ }^{99 \mathrm{~m}} \mathrm{Tc}-$ labeled cercaria did not loose its motility and infectivity, and it is possible to study its migration in albino mice (Bernardo-Filho et al. 1992). The administration of a ${ }^{99} \mathrm{~m}$ Tc-labeled oxamniquine solution in infected mice reveals its uptake in specific organs and in the adult worms (Rebello et al. 1994).

In order to evaluate the action mode of sodium phenobarbital to move adult worms (worm shift) from mesenteric veins to the liver, we have labelled sodium phenobarbital with ${ }^{99 \mathrm{~m}} \mathrm{Tc}$ and have studied the biodistribution study of this radiotracer in $S$. mansoni infected swiss mice.

\section{MATERIALS AND METHODS}

Experimental infection - Twenty seven males and females outbreed mice (seven-day-old) were infected through transcutaneous route with 80 cercariae of S. mansoni (BH strain, Brazil).

Labelling study - To stablish the optimal stannous chloride $\left(\mathrm{SnCl}_{2} \cdot 2 \mathrm{H}_{2} \mathrm{O}\right)$ concentration, $0.5 \mathrm{mg} /$ $\mathrm{ml}$ of sodium 5 ethil-5-phenilbarbiturate (PBTT) $(1.0 \mathrm{mg} / \mathrm{ml})$, in vacuum tubes, was incubated $(10$ min, room temperature) with $0.5 \mathrm{ml}$ of various stannous chloride solutions $(0.01,0.1,1,5$, and 10 $\mathrm{mg} / \mathrm{ml})$. Then, ${ }^{99 \mathrm{~m}} \mathrm{Tc}(18.5 \mathrm{MBq} / \mathrm{ml})$, as sodium pertechnetate, recently milked from a ${ }^{99 \mathrm{~m}} \mathrm{Tc} /{ }^{99} \mathrm{Mo}$ generator (Instituto de Pesquisas Energéticas e Nucleares, Comissão Nacional de Energia Nuclear, Brazil) was added and the incubation continued for another $10 \mathrm{~min}$.

Radiochemical control - The percentage of radioactivity (\% rad) present in the sodium 5 ethil5-phenilbarbiturate fraction was determined using strips $(8 \times 0.8 \mathrm{~cm})$ of Whatman chromatography paper. One drop $(2 \mu \mathrm{l})$ of ${ }^{99 \mathrm{~m}} \mathrm{Tc}-\mathrm{PBBT}$ solution was spotted $1 \mathrm{~cm}$ from the bottom of three strips. Solution of $0.9 \% \mathrm{NaCl}$ and acetone were employed as mobile phases, to test their ability to separate free ${ }^{99 \mathrm{~m}} \mathrm{Tc}$ and ${ }^{99 \mathrm{~m}} \mathrm{Tc}$-colloid from ${ }^{99 \mathrm{~m}} \mathrm{Tc}-\mathrm{PBBT}$.

Radiochemical stability - Chromatography of the labeled sodium 5 ethil-5-phenilbarbiturate with the best stannous chloride concentration $(0.01 \mathrm{mg} /$ $\mathrm{ml}$ ) was carried out at different times after the labeling reaction to evaluate the labeling stability (1, 2, 3, 4, $5 \mathrm{hr}$ ).

Biodistribution study - ${ }^{99 \mathrm{~m}} \mathrm{Tc}-\mathrm{PBBT}(10 \mathrm{mg} /$ wb) labeled with stannous chloride $0.01 \mathrm{mg} / \mathrm{ml}$ was administered, intraperitoneal route, in infected (56 days after the infection)and not infected mice. After a variable period of time has elapsed $(0,1,2,3$, $4 \mathrm{hr}$ ) the animals were sacrificed by cervical displacement and perfused (Machado-Silva et al. 1993). Adult worms, blood, mesenteric vessels, portal vein, stomach, liver, brain, spleen, muscles, intestines, heart and kidneys were isolated. The ra- dioactivity present in these samples was counted in a well counter. The percentage of radioactivity per gram of tissue was determined for each sample as related elsewhere (Rebello et al. 1994).

Statistical analysis - Analysis of variance (ANOVA) considering $\mathrm{p} \leq 0.05$ was perfomed (Remington \& Schork 1985).

\section{RESULTS}

The study with several stannous chloride concentrations reveals that high labeling yields of the PBBT with ${ }^{99 \mathrm{~m}} \mathrm{Tc}$ are achieved from the concentration of the reducing agent of the $0.01 \mathrm{mg} / \mathrm{ml}$. Free ${ }^{99 \mathrm{~m}} \mathrm{Tc}$ migrates with the mobile phase when the chromatographies were performed with $0.9 \%$ $\mathrm{NaCl}$ solution or acetone. The ${ }^{99 \mathrm{~m}} \mathrm{Tc}-\mathrm{PBBT}$ remains in the origin, independently of the stannous chloride concentration used and the yield of the labeling $>90 \%$.

Table I shows the results obtained from the incubation of a ${ }^{99 \mathrm{~m}} \mathrm{Tc}-\mathrm{PBBT}$ in different period of time after the labeled process. This labeled molecule is stable in in vitro and the percentage of the radiocativity is not practically modified up to $2 \mathrm{hr}$, although a sligtly reduced is observed after this time.

\section{TABLE I}

Evaluation of the stability of the labeled sodium 5 ethil-5-phenilbarbiturate with technetium-99m in different elapsed times after the labeled process.

Acetone was employed as mobile phase of the chromatography. The chromatography was carried out and the percentage of the radioactivity was determined

in the bottom and the top of the stationary phase (paper strips)

\begin{tabular}{lcc}
\hline Time (hr) & Bottom (\%) & Top (\%) \\
\hline 0 & 92.8 & 7.2 \\
1 & 92.6 & 7.4 \\
2 & 92.5 & 7.5 \\
3 & 91.5 & 8.5 \\
4 & 91.3 & 8.7 \\
5 & 90.6 & 9.4 \\
\hline
\end{tabular}

Table II shows the biodistribution (\%) of ${ }^{99 \mathrm{~m}} \mathrm{Tc}-$ PBBT/g in healthy (not infected) mice in different periods of time after the administration of the labeled drug. After $1 \mathrm{hr}$, the radioactivity is found in the kidney $(11.4 \%)$. The radioactivity decreased with the time in the spleen from $6.9(0 \mathrm{hr})$ to $2.7(4$ hr), in the liver from 5.8 to $3.6 \%$ and in the intestines from 5.8 to $4 \%$. It is observed an increasing of the ${ }^{99 \mathrm{~m} T c-P B B T}$ in mesenteric system from 3.9 to $5.5 \%$ and in portal vein from 6.5 to $13.3 \%$ in the same considered times. 
Table III shows the biodistribution $(\%)$ of ${ }^{99} \mathrm{~m} \mathrm{Tc}-$ $\mathrm{PBBT} / \mathrm{g}$ in infected mice in different periods of time after the administration of the labeled drug. The radioactivity uptake in the spleen, in the liver and in the bowels is reduced $(\mathrm{p}<0.05)$ when compared with the healthy animals. However, the fixation of radioactivity is not practically modified in the kidney, in mesenteric system and in portal vein in the same considered times. Radioactivity was not found on the adult worms in the infected mice either.

\section{TABLE II}

The biodistribution study of ${ }^{99 \mathrm{~m}} \mathrm{Tc}$-PBTT in not infected mice. The radioactivity present in different specimens was determined in various periods of time in a well counter. The percentage of radioactivity per gram of tissue was calculated in each specimen

\begin{tabular}{lccccc}
\hline Specimens & \multicolumn{5}{c}{ Time (hr) } \\
\cline { 2 - 6 } & 0 & 1 & 2 & 3 & 4 \\
\hline Blood & $5.3 \pm 0.5$ & $3.0 \pm 0.3$ & $2.5 \pm 0.3$ & $2.0 \pm 0.1$ & $2.0 \pm 0.1$ \\
Liver & $1.3 \pm 0.2$ & $2.5 \pm 0.3$ & $2.0 \pm 0.2$ & $0.9 \pm 0.08$ & $0.7 \pm 0.01$ \\
Intestines & $0.7 \pm 0.06$ & $1.8 \pm 0.1$ & $0.5 \pm 0.04$ & $0.5 \pm 0.03$ & $1.2 \pm 0.01$ \\
Stomach & $0.6 \pm 0.04$ & $0.7 \pm 0.06$ & $1.1 \pm 0.1$ & $3.5 \pm 0.3$ & $3.4 \pm 0.3$ \\
Kidneys & $2.3 \pm 0.2$ & $12.2 \pm 1.5$ & $11.2 \pm 1.3$ & $6.5 \pm 0.5$ & $6.4 \pm 0.6$ \\
Spleen & $0.6 \pm 0.06$ & $0.8 \pm 0.07$ & $0.3 \pm 0.01$ & $0.3 \pm 0.02$ & $0.3 \pm 0.01$ \\
Heart & $1.0 \pm 0.06$ & $0.8 \pm 0.07$ & $0.4 \pm 0.03$ & $0.4 \pm 0.01$ & $0.3 \pm 0.03$ \\
Lungs & $1.1 \pm 0.1$ & $1.2 \pm 0.2$ & $1.3 \pm 0.1$ & $0.5 \pm 0.04$ & $0.6 \pm 0.06$ \\
Muscle & $0.3 \pm 0.03$ & $0.8 \pm 0.07$ & $0.4 \pm 0.03$ & $0.6 \pm 0.05$ & $0.2 \pm 0.02$ \\
Brain & 0.0 & 0.0 & 0.0 & 0.0 & 0.0 \\
Mesenteric & $3.3 \pm 0.3$ & $4.7 \pm 0.5$ & $5.1 \pm 0.4$ & $5.6 \pm 0.5$ & $6.0 \pm 0.5$ \\
Portal vein & $5.4 \pm 0.5$ & $9.0 \pm 0.8$ & $9.8 \pm 0.9$ & $10.7 \pm 1.0$ & $13.9 \pm 1.1$ \\
Mesenteric worms & - & - & - & - & - \\
Liver worms & - & - & - & - & - \\
\hline
\end{tabular}

TABLE III

The biodistribution study of ${ }^{99 \mathrm{~m}} \mathrm{Tc}-\mathrm{PBTT}$ in infected mice. The radioactivity present in different specimens was determined in various periods of time in a well counter. The percentage of radioactivity per gram of tissue was calculated in each specimen

\begin{tabular}{lccccc}
\hline Specimens & \multicolumn{5}{c}{ Time (hr) } \\
\cline { 2 - 6 } & 0 & 1 & 2 & 3 & 4 \\
\hline Blood & $3.3 \pm 0.2$ & $2.2 \pm 0.2$ & $0.8 \pm 0.08$ & $1.6 \pm 0.1$ & $1.2 \pm 0.1$ \\
Liver & $5.8 \pm 0.5$ & $4.0 \pm 0.4$ & $2.7 \pm 0.2$ & $2.4 \pm 0.3$ & $3.6 \pm 0.3$ \\
Intestines & $5.8 \pm 0.5$ & $4.6 \pm 0.4$ & $4.0 \pm 0.3$ & $3.0 \pm 0.2$ & $4.0 \pm 0.4$ \\
Stomach & $3.9 \pm 0.4$ & $4.4 \pm 0.5$ & $5.7 \pm 0.5$ & $3.9 \pm 0.3$ & $5.2 \pm 0.5$ \\
Kidneys & $3.4 \pm 0.3$ & $11.4 \pm 1.0$ & $9.3 \pm 0.9$ & $7.8 \pm 0.7$ & $6.1 \pm 0.5$ \\
Spleen & $6.9 \pm 0.6$ & $5.1 \pm 0.5$ & $3.9 \pm 0.4$ & $4.1 \pm 0.4$ & $2.7 \pm 0.3$ \\
Heart & $0.9 \pm 0.08$ & $0.7 \pm 0.06$ & $0.6 \pm 0.05$ & $0.5 \pm 0.05$ & $0.4 \pm 0.03$ \\
Lungs & $1.0 \pm 0.1$ & $1.4 \pm 0.1$ & $1.0 \pm 0.1$ & $0.6 \pm 0.07$ & $1.2 \pm 0.1$ \\
Muscle & $0.6 \pm 0.06$ & $0.8 \pm 0.09$ & $0.6 \pm 0.06$ & $0.4 \pm 0.01$ & $0.4 \pm 0.02$ \\
Brain & 0.0 & 0.0 & 0.0 & 0.0 & 0.0 \\
Mesenteric & $3.9 \pm 0.4$ & $3.1 \pm 0.3$ & $3.8 \pm 0.3$ & $4.3 \pm 0.4$ & $5.5 \pm 0.4$ \\
Portal vein & $6.5 \pm 0.6$ & $7.8 \pm 0.8$ & $6.2 \pm 0.6$ & $7.7 \pm 0.7$ & $13.3 \pm 1.4$ \\
Mesenteric worms & 0.0 & 0.0 & 0.0 & 0.0 & 0.0 \\
Liver worms & 0.0 & 0.0 & 0.0 & 0.0 & 0.0 \\
\hline
\end{tabular}




\section{DISCUSSION}

Barbiturate drugs are commonly employed as anesthaetic ones in the surgical routine and in the experimental one in laboratory animals (Zanini \& Oga 1982). When these drugs are administered to S. mansoni infected mice, a migration of the worms from mesenteric vessels to the liver is observed (Khayyal 1965). Furthermore, this effect is very strong when the anesthaetic is administered by peritoneal route (Machado-Silva et al. 1993) and presents vasodilatador action (Machado-Silva et al. 1996). However, this action mechanism of the anesthesic is not elucidated: if the effect of the drug is direct (i) in the adult worm and/or (ii) in the host. Authors have reported a depressant action on the central ganglion of the worm or their paralysis after a decreasing in their electrical activity (Khayyal 1965, Semeyn et al. 1982, Mellin et al. 1983).

The quantification of radioactivity in adult worms of the $S$. mansoni has been possible. The methodology using radionuclide has been adequate to evaluate the fixation of ${ }^{99 \mathrm{~m}} \mathrm{Tc}$-oxamniquine into adult worms (Rebello et al. 1994).

Our results indicate that the phenobarbital seems to have an indirect action in the adult worms due to the radioactivity of ${ }^{99 \mathrm{~m}} \mathrm{Tc}$-labeled drug was not found in the worms (Table III). The biodistribution study of the ${ }^{99 \mathrm{~m}} \mathrm{Tc}-\mathrm{PBBT}$ reveals the presence of an important amount of radioactivity in the liver, portal vein, mesenteric vessels, spleen, intestines and kidneys.

A decreasing in the blood flowing, an increasing in the blood pressure and in the vessel lumen have been described after the administration of sodium phenobarbital(Machado-Silva et al. 1996).

Hepatic and renal vessels have $\beta$-adrenergic receptors when these receptors are stimulated, they induce vasodilatation (Zanini \& Oga 1982). They probably are binding sites to the sodium phenobarbital due to this drug is a vasodilator one.

The biodistribution of radiopharmaceuticals can be altered due to various factors as drug interaction, radiation therapy or diseases (Goodman \& Gilman 1991). The anatomical, histological and physiopathlogical alterations due to the schistosomiasis infection could justify the decreasing of the radioactivity uptake in liver and spleen (Coelho et al. 1977). In the S. mansoni infected animals there is a severe diminishement of the hepatic function and its capacity to metabolize drugs is reduced due to the microsomial enzyme activities are altered (Cha et al. 1980).

\section{REFERENCES}

Bernardo-Filho M, Gutfilen B, Maciel OS 1994. Effect of different anticoagulants on the labelling of red blood cells and plasma proteins with Tc-99m. Nucl
Med Comm 15: 730-734.

Bernardo-Filho M, Machado-Silva JR, Reis RJ, Boasquevisque EM, Hason Voloch A 1992. Conditions for labelling of Schistosoma mansoni cercaria with technetium-99m. J Nucl Biol Med 36: 56-59.

Cha YN, Heine HS, Bueding E 1980. Effect of Schistosoma mansoni infection on hepatic drug-metabolizing capacity of athymic nude mice. Am J Trop Med Hyg 29: 234-238.

Christensen NO 1977. A method for the in vivo labelling of Schistosoma mansoni and S. intercalatum cercariae with radioselenium. Z Parasitenk 54: 275 288.

Coelho PMZ, Freire ACT, Araujo FG, Pellegrino J, Pereira LH 1977. Effect of Schistosoma mansoni infection on pentobarbital-induced sleeping-time in mice. Am J Trop Med Hyg 26: 186-187.

Cunha-Melo JR, Coelho PMZ 1986. Schistosoma mansoni: effects of anesthetics and antimonial drugs on worm shift in the mouse. Rev Inst Med Trop $S$ Paulo 28: 267-270.

Early PJ, Soddee DB 1995. Principles and Practice of Nuclear Medicine. Mosby - Year Book, Inc., Toronto, 877 pp.

Goldsmith EI, Kean BH 1966. Schistosomiasis: Experimental surgical removal of adult worms. Gastroenterology 50: 805-807.

Goodman LSC, Gilman A 1991. As Bases Farmacológicas da Terapêutica, $8^{\mathrm{a}}$ ed., Guanabara Koogan, Rio de Janeiro, RJ, 1231 pp.

Hladik III WB, Saha GB, Study KT 1987. Essentials of Nuclear Medicine Sciences. William \& Wilkins, Sydney, 439 pp.

Khayyal MT 1965. Significance of worm shift in experimental schistosomiasis mansoni infection with emphasis on the action of anesthetics. Nature 205: 1331-1332.

Machado e Silva JR, Lima MAD, Rodrigues e Silva R, Maldonado Jr A, Presgrave OAF, Rey L 1993. Comparative study on the localization of adult Schistosoma mansoni worms in albino mice anesthetized with pentobarbital sodium, ether or chloroform. Rev Inst Med Trop S Paulo 35: 323-326.

Machado-Silva JR, Simões SBE, Alves AC, Oliveira RMF, Martinez EM, Presgrave OAF 1996. Schistosoma mansoni Sambon, 1907: effects of dilatation and constricting anesthetics drugs on adult worms localization in swiss mice. Rev Inst Med Trop S Paulo 38: 103-111.

Mellin TM, Busch RD, Wang CC, Kath G 1983. Neuropharmacology of the parasitic trematode, Schistosoma mansoni. Am J Trop Med Hyg 32: 83-93.

Motta JG, Vianna W, Prata A 1968. Migração de $S$. mansoni em camundongos por drogas usadas em anestesia. Gaz Med Bahia 68: 19-24.

Pinto RM, Almeida MSS, Noronha D, Katz N, Tendler M 1990. Autoradiographic analysis of Schistosoma mansoni migration in the NZ rabbit. Mem Inst Oswaldo Cruz 85: 91-94.

Rebello LHS, Machado-Silva JR, Gutfilen B, BernardoFilho M 1994. Oxamniquine: a labelling procedure with technetium-99m and biodistribution study in mice. J Nucl Biol Med 38: 109-112. 
Remington RD, Schork MA 1985. Statistics with applications to the biological and health sciences. Prentice-Hall, Inc., New Jersey, 415 pp.

Ripoll-Hamer E, Freitas LC, Paula EF, Fonseca LM, Gutfilen B, Bernardo-Filho M 1995. In vitro effect of cyclophosphamide on the binding of radiopharmaceuticals $\left({ }^{99} \mathrm{~m} \mathrm{TcO}_{4}{ }^{-}\right.$and $\left.{ }^{99 \mathrm{~m}} \mathrm{Tc}-\mathrm{MDP}\right)$ to blood elements. Braz J Med Biol Res 28: 256260.

Saha GB 1992. Fundamentals of Nuclear Pharmacy. Springer-Verlag, New York, 331 pp.

Santos JS, Paula EF, Correa TG, Freitas LC, Fonseca
LM, Gutfilen B, Bernardo-Filho M 1995. Effect of cyclophosphamide on the binding of ${ }^{99} \mathrm{~m} \mathrm{TcO}_{4}{ }^{-}$and ${ }_{99 \mathrm{~m}}$ Tc-MDP to blood cells and plasma proteins. $\mathrm{Braz}$ J Med Biol Res 28: 131-135.

Semeyn DR, Pax RA, Bennett JL 1982. Surface electrical activity from Schistosoma mansoni: a sensitive measure of drug action. J Parasitol 68: 353-362.

Woolhouse NN, Kaye B 1977. Uptake of [14C] oxamniquine by Schistosoma mansoni. Parasitology 75: 111-118.

Zanini AC, Oga S 1982. Farmacologia aplicada. Atheneu, São Paulo, SP, 277 pp. 